\title{
Autonomic Function and Control of Pancreatic Somatostatin
}

\author{
E. Samols, J. I. Stagner, and G. C. Weir \\ Veterans Administration Medical Center and Department of Medicine, University of Louisville School of Medicine, Louisville, Kentucky, \\ and Department of Medicine, Medical College of Virginia, Richmond, Virginia, USA
}

Summary. In the canine pancreas alpha and beta adrenergic receptors exist on $\mathrm{D}$ cells with $\alpha$ stimulation inhibiting and $\beta$ stimulation increasing somatostatin release. There are no dopaminergic receptors on D cells. Stimulation of muscarinic receptors causes mild inhibition of somatostatin secretion. Autonomic receptors on the $\mathrm{D}$ cell may be physiologically stimulated in vivo via local ganglionic and/or central autonomic drivers.

Key words: Somatostatin, insulin, glucagon, adrenergic receptors, cholinergic receptors, pancreas, autonomic, dopamine, acetylcholine.

It is currently convenient to subdivide "potential" autonomic modulation of the endocrine pancreas into adrenergic, dopaminergic and cholinergic components. Adrenergic and cholinergic influence on insulin secretion has been clearly demonstrated, and specific dopaminergic (non-adrenergic) effects on A and $B$ cells have recently been suggested [1]. However, information on the autonomic control of somatostatin and of glucagon secretion has either been scanty or controversial $[2,3,4,5,6]$. The present studies were designed to examine the effects of chemical autonomic agonism on insular D, A and B cell secretion in the isolated perfused canine pancreas. To avoid flaws in previous studies, we tried to ensure adequate "specific" agonism and appropriate antagonism by using a dose range of putative agonists and antagonists, the latter being used both individually and in combination.

\section{Materials and Methods}

Fasting mixed-breed German shepherd dogs weighing $20-25 \mathrm{~kg}$ were used as pancreas donors. Methods used in pancreatectomy and perfusion are described in detail elsewhere [4]. Throughout the studies, perfusate glucose concentration was maintained at $88 \mathrm{mg} / \mathrm{dl}$ except where specifically noted. The perfusate consisted of Krebs-Ringer buffer, $\mathrm{pH} 7.3-7.4$, containing 4\% dextran, electrolytes, and a $1 \mu \mathrm{mol} / 1$ amino acid mixture [4]. Temperature, pressure and flow rate were monitored throughout each perfusion of $215 \mathrm{~min}$. Samples were obtained from the efflux at $1 \mathrm{~min}$ intervals by means of a fraction collector. Insulin (IRI), somatostatin (IRS) and glucagon (IRG) were measured by radioimmunoassay and a charcoal separation technique [4].

The pancreas was perfused for $30-40 \mathrm{~min}$ before the infusion of catecholamines (L-adrenaline, L-noradrenaline, dl-isoprenaline, dopamine), apomorphine, acetylcholine (hydrobromide) or receptor blockers (including dl-propranolol, phentolamine (CIBA Corp., Summit, N. J.), phenoxybenzamine hydrochloride (a gift from Smith, Kline \& French Labs., Philadelphia, PA), butaclamol (a gift from Ayerst Research Labs., Montreal, Canada) and haloperidol (a gift from McNeil Labs., Fort Washington, PA).

The duration of the agonist infusions was invariably 10 minutes. Receptor blockade was given for varying periods (the minimum being $15 \mathrm{~min}$ ) before agonist infusion and several permutations in antagonist/agonist administration were used in terms of order of administration.

Statistical analysis of the results was performed by Student's two-tailed t-test, using percentage change of hormone sampled at each minute compared with the preagonism or preantagonism mean for -5 to $-1 \mathrm{~min}$. Tested in this fashion, the zero-minute sample (shown in the figures) was not significantly different from the preagonism or preantagonism mean. The mean percent integrated change during agonism or antagonism was calculated as the simple mean of the mean change for each experiment, and is reported as mean percentage change in the text.

\section{Results}

\section{Effect of Beta-adrenergic Agonism}

As shown in Figure 1, isoprenaline $(2 \mathrm{ng} / \mathrm{ml})$ stimulated somatostatin, insulin and glucagon secretion. The stimulation of somatostatin (Mean \pm SEM, $79 \pm 20 \%)$, insulin $(495 \pm 146 \%)$ and glucagon $(185 \pm 45 \%)$ was abolished by propranolol.

\section{Effect of Alpha-adrenergic Agonism}

Infusion of adrenaline $(2 \mathrm{ng} / \mathrm{ml})$ did not change pancreatic somatostatin secretion. After beta-adrenergic blockade with propranolol, the infusion of adrenaline 


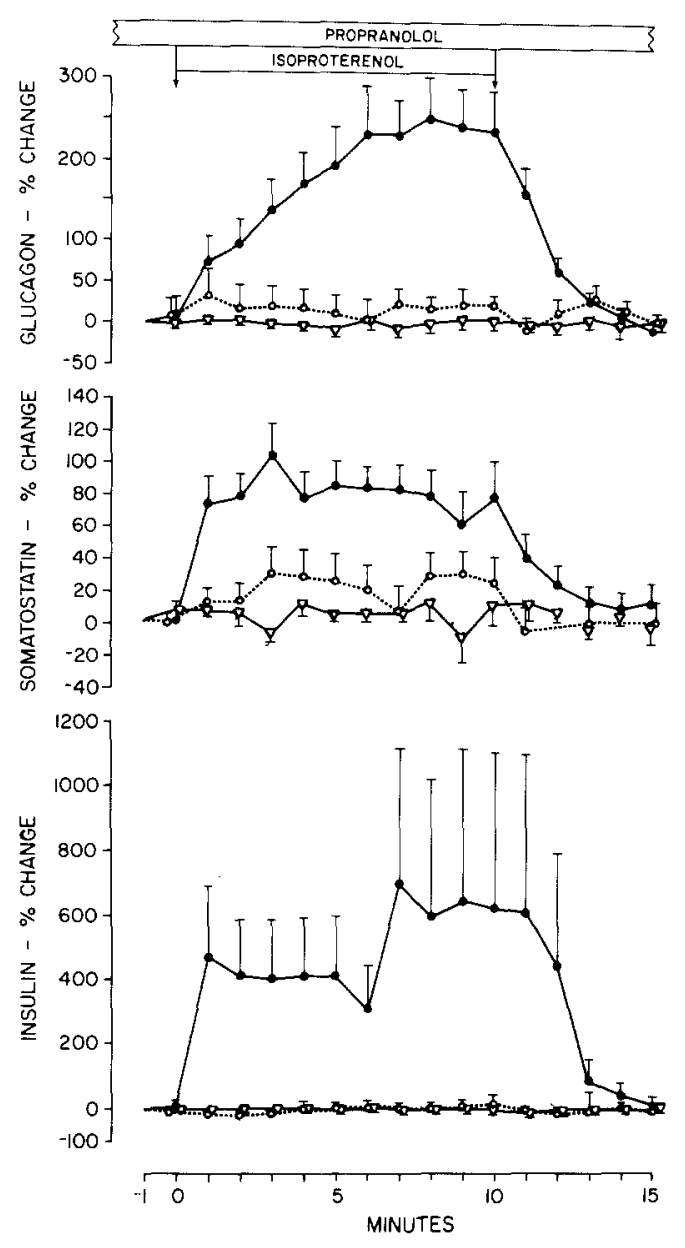

Fig. 1. Effect of isoprenaline (isoproterenol). Mean percentage change of glucagon, somatostatin, and insulin ( \pm SEM) during $2 \mathrm{ng} / \mathrm{ml}$ isoprenaline $(\mathrm{n}=8), 0$; isoprenaline after $\beta$-adrenergic blockade with $2 \mu \mathrm{mol} / \mathrm{l}$ propranolol $(\mathrm{n}=5), 0$; and isoprenaline after $6 \mu \mathrm{mol} / 1$ propranolol $(n=6), \nabla$. The zero time sample (immediately before agonism) was derived from preagonism mean of -5 to $-1 \mathrm{~min}$. During the 10 -min infusion of isoprenaline alone, mean changes were significant $(2 \mathrm{P}<0.05)$ for glucagon (last $9 \mathrm{~min}$ ), somatostatin (10 min), and insulin (first $6 \mathrm{~min}$ ). After blockade, the changes were not significant. (From [4])

$(2 \mathrm{ng} / \mathrm{ml}$ or $10 \mathrm{ng} / \mathrm{ml})$ induced decreases in somatostatin secretion (Table 1). However, after combined alpha plus beta-adrenergic blockade, adrenaline either failed to inhibit somatostatin release or actually induced a small increase in somatostatin. With the addition of atropine to the combined adrenergic blockade, the infusion of adrenaline caused no change in somatostatin release. In these experiments, alpha-adrenergic agonism significantly decreased insulin secretion by -77 to $-85 \%$, and increased glucagon secretion by 64 to $95 \%$ [4].

\section{Effect of Dopaminergic Agonism}

Dopamine $10 \mu \mathrm{mol} / 1$ did not change somatostatin secretion (Table 2). After beta-adrenergic blockade
Table 1. Effect of $\alpha$-adrenergic agonism on pancreatic somatostatin

\begin{tabular}{llrl}
\hline Adrenaline & Antagonist & \multicolumn{1}{l}{$\Delta \%$} & $2 \mathrm{P}$ \\
\hline $2 \mathrm{ng} / \mathrm{ml}$ & - & $-7 \pm 9$ & NS \\
& PROP $2 \mu \mathrm{mol} / \mathrm{l}$ & $-23 \pm 4$ & $<0.01$ \\
& PROP $4 \mu \mathrm{mol} / 1$ & $-27 \pm 4$ & $<0.005$ \\
& PROP $2 \mu \mathrm{mol} / 1$ & $17 \pm 4$ & $<0.01$ \\
& DBZ $3 \mu \mathrm{mol} / 1$ & & \\
& PROP $4 \mu \mathrm{mol} / 1$ & $11 \pm 5$ & NS \\
& PHEN $4 \mu \mathrm{mol} / 1$ & & \\
\hline $10 \mathrm{ng} / \mathrm{ml}$ & PROP $4 \mu \mathrm{mol} / 1$ & $-37 \pm 7$ & $<0.005$ \\
& PROP $4 \mu \mathrm{mol} / 1$ & $8 \pm 2$ & $<0.02$ \\
& PHEN $4 \mu \mathrm{mol} / 1$ & & \\
& PROP $4 \mu \mathrm{mol} / 1$ & $1 \pm 4$ & NS \\
& PHEN $4 \mu \mathrm{mol} / 1$ & & \\
& ATROPINE $5 \mu \mathrm{mol} / 1$ &
\end{tabular}

Abbreviations: PROP $=$ Propranolol, $\mathrm{DBZ}=$ Dibenzylene PHEN $=$ Phentolamine

with propranolol $4 \mu \mathrm{mol} / 1$, dopamine induced a significant decrease in somatostatin release. After alpha-adrenergic blockade with phentolamine $4 \mu \mathrm{mol} / \mathrm{l}$, dopamine increased somatostatin secretion. However, after combined alpha plus beta-adrenergic blockade (Table 2), the infusion of dopamine caused no change in somatostatin release.

Because of the relatively small changes in D cell secretion, the search for a possible specific dopaminergic receptor modulating insular secretions was pursued in greater depth with respect of the B cell. Insulin release was inhibited by $10 \mu \mathrm{mol} / \mathrm{l}$ dopamine $(-70 \pm 40 \%)$ and apomorphine $(-62 \pm 4 \%)$. After blockade with propranolol, dopamine $(-69 \pm 2 \%)$ and apomorphine $(-70 \pm 8 \%)$ inhibited insulin release to a similar degree. After blockade with phentolamine, dopamine $(255 \pm 40 \%)$ and apomorphine $(60 \pm 20 \%)$ stimulated insulin secretion. Combined blockade with propranolol plus phentolamine abolished the previous effects of dopamine $(12 \pm 5 \%)$ or apomorphine $(12 \pm 5 \%)$ on insulin release.

"Specific" dopaminergic blockade with butaclamol partially neutralized the inhibitory effect of apomorphine plus propranolol on insulin release, and complete abolition was achieved by blockade with butaclamol plus dibenzylene. Although butaclamol did not show demonstrable alpha-adrenergic antagonism at higher doses of adrenaline $(10 \mathrm{ng} / \mathrm{ml})$ plus propranolol, butaclamol did abolish the inhibition of insulin release $(-47 \%)$ by adrenaline $0.4 \mathrm{ng} / \mathrm{ml}$ on a background of propranolol.

Because we were unable to demonstrate an effect with haloperidol, the paradigmatic dopaminergic 


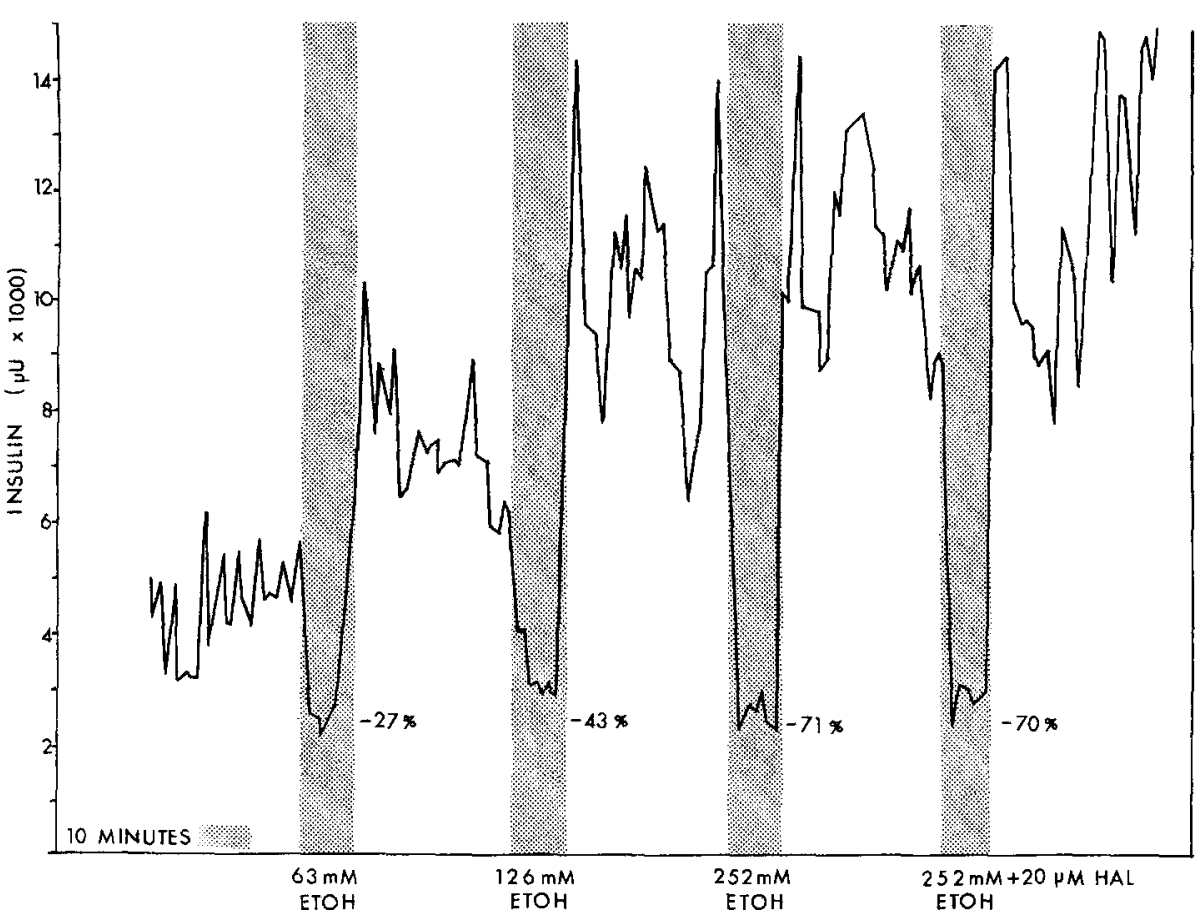

Fig. 2. Effect of ethanol $(63,126$, $252 \mathrm{mmol} / \mathrm{l}$ ) and $20 \mu \mathrm{mol} / \mathrm{l}$ haloperidol in ethanol $(252 \mathrm{mmol} / \mathrm{l})$ on the secretion of insulin in a representative experiment. The glucose concentration was $200 \mathrm{mg} / \mathrm{dl}$ with $2.65 \mathrm{mmol} / 1$ calcium. Samples were at $1 \mathrm{~min}$ intervals. Ethanol and ethanol/haloperidol (Hal) were infused for $10 \mathrm{~min}$. Thirty minute periods between infusions were to reestablish baseline values or as a recovery period. (From [11])

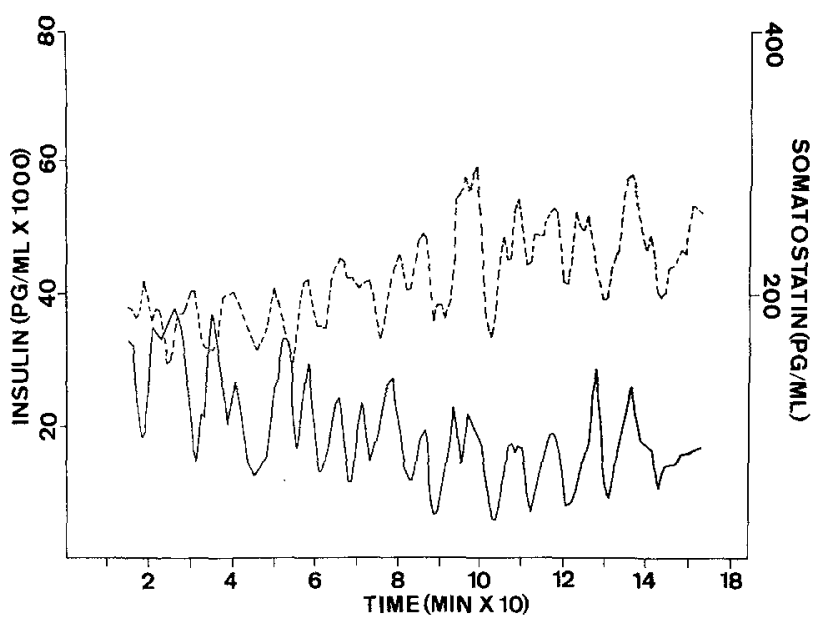

Fig. 3. Insulin and somatostatin cycles. Comparison of insulin (solid line) and somatostatin (broken line) cycles from a representative single pancreas. After an initial equilibration period cycles become regular and closely matched in frequency. Cycles persisted throughout the period of study in all perfusions. (From [8])

Table 2. Effects of dopamine $(10 \mu \mathrm{mol} / \mathrm{l})$ on somatostatin secretion after propranolol $(4 \mu \mathrm{mol} / \mathrm{l})$ and/or phentolamine $(4 \mu \mathrm{mol} / \mathrm{l})$. Values are percentage change \pm SEM

\begin{tabular}{llll}
\hline $\begin{array}{c}\text { DOPAMINE } \\
\begin{array}{l}+ \\
\text { PROP }\end{array}\end{array}$ & $\begin{array}{l}\text { DOPAMINEN } \\
\text { PHEN }\end{array}$ & $\begin{array}{l}\text { DOPAMINE } \\
+ \\
\text { PROP + PHEN }\end{array}$ \\
\hline$-5 \pm 3$ & $-23 \pm 2$ & $52 \pm 6$ & $2 \pm 3$
\end{tabular}

Abbrevations: PROP $=$ Propranolol, PHEN $=$ Phentolamine antagonist, in the isolated canine pancreas, we were bemused by the report that haloperidol [7] induced a dose dependent inhibition of insulin and glucagon release. We thought it possible that the inhibition of insular secretions (including somatostatin) had been caused by ethanol, used as a solvent for haloperidol. Haloperidol $(5-20 \mu \mathrm{mol} / \mathrm{l})$ dissolved in ethanol did not augment the inhibitory effects of ethanol on insulin (Fig. 2), somatostatin or glucagon secretion [8].

\section{Effect of Cholinergic Agonism}

Acetylcholine (0.1, 0.2, 1.5 and $10 \mu \mathrm{mol} / 1)$ infusions induced a dose dependent increase in insulin and glucagon secretion, and a small decrease in somatostatin secretion. The maximal responses occurred during acetylcholine $(5 \mu \mathrm{mol} / \mathrm{l})$ infusion (insulin $480 \pm 91 \%)$, glucagon $(164 \pm 24 \%)$, somatostatin $(-32 \pm 3 \%)$ with an approximate $\mathrm{ED}_{50}=0.7 \mu \mathrm{mol} / 1$ acetylcholine for insulin and glucagon. After blockade with atropine sulfate $(5 \mu \mathrm{mol} / \mathrm{l})$, the infusion of acetylcholine induced no major change in insulin $(13 \pm 4 \%)$, glucagon $(0 \pm 2 \%)$ or somatostatin $(6 \pm 2 \%)$.

In order to test whether the acetylcholine effect might be mediated via ganglionic stimulation of adrenergic nerves, acetylcholine $(5 \mu \mathrm{mol} / 1)$ was infused after blockade with dibenzylene, and a small decrease in somatostatin secretion $(-16 \pm 2 \%)$ was again observed. 


\section{Effects of Autonomic Antagonism on Insular Humoral Oscillations}

Sustained regular oscillations of somatostatin had the same cycle mean, $10 \mathrm{~min}$, as insulin (Fig. 3) [9-11]. Cycles were disrupted by dopamine, apomorphine, adrenaline and acetylcholine [10] but were generally reestablished after a variable time. To test whether cycles might be driven by a local autonomic circuit, coordinated by ganglia, the effect of autonomic blockade was studied. Cycles were not disrupted by blockade with atropine, propranolol, dibenzylene, phentolamine or butaclamol [10] whether these antagonists were given singly or in combination.

\section{Discussion}

The isolated canine pancreas preparation contains the pancreatic insular organ, nerves and (presumably) ganglia. Our results strongly suggest that there are indeed alpha and beta-adrenergic receptors on $D$ and A cells. D cell secretion, like that of the B cell, was inhibited by alpha-adrenergic agonism and was stimulated by beta-adrenergic agonism. However, the adrenergic induced changes in D-cell secretion were smaller in magnitude than those of B-cell secretion [4]. In contrast, the A cell was moderately stimulated by alpha-adrenergic agonism and markedly stimulated by beta-adrenergic agonism [4].

We conclude that there are no specific dopaminergic receptors on pancreatic insular cells. The possibility that "specific" dopaminergic effects might be mediated through small intensely fluorescent cells in ganglia cannot be excluded without electrical stimulation studies. Apomorphine is not a "specific" dopaminergic agonist in the pancreas, as it stimulates alpha-adrenergic receptors. "Blockade" by butaclamol is best explained as being due to mild alpha-adrenergic antagonism. As there are large amounts of dopamine in the pancreatic islets [12] we suggest that any cellular effects of this dopaminergic system are mediated through alpha- (or beta) adrenergic receptors $[5,6]$.

Acetylcholine, a potent stimulant of insulin and glucagon secretion, caused a mild inhibition of somatostatin secretion [2, 3]. As these inhibitory effects were blocked by atropine, we conclude that the inhibition is induced by muscarinic receptor agonism. As dibenzylene failed to block the inhibition, a "secondary" or post-ganglionic alphaadrenergic effect is unlikely. Hermansen et al. [13] reported that acetylcholine $(1 \mu \mathrm{mol} / 1)$ stimulates somatostatin release in the isolated canine pancreas.
These workers used a perfusate containing a low concentration of calcium. In our hands a dose range of acetylcholine $0.1-50 \mu \mathrm{mol} / 1$ failed to stimulate somatostatin release.

Acknowledgement. This study was supported by the Veterans Administration and National Institutes of Health, AM-00255.

\section{References}

1. Lorenzi M, Karam JH, Tsaukian E, Bohnanon NV, Gerich JE, Forsham PH (1979) Dopamine during $\alpha$ - or $\beta$-adrenergic blockade in man. J Clin Invest 63: 310-317

2. Samols E, Weir GD, Patel YC, Loo SW, Gabbay KH (1977) Autonomic control of somatostatin and pancreatic peptide secretion by the isolated perfused canine pancreas (Abstr). Clin Res 25 [Suppl 3]: 499A

3. Samols E, Weir GC, Ramseur R, Day JA, Patel YC (1978) Modulation of pancreatic somatostatin by adrenergic and cholinergic agonism and by hyper- and hypoglycemic sulfonamides. Metabolism 27 [Suppl I]: 1219-1221

4. Samols E, Weir GC (1979) Adrenergic modulation of pancreatic A, B and D cells. J Clin Invest 63: 230-238

5. Samols E, Stagner J, Weir GC (1979) Presynaptic dopaminergic modulation of pancreatic insular secretions (Abstract). Diabetes 28: 371

6. Samols E, Stagner JI (1979) Dopaminergic receptors are present in the pancreas and influence $A$ and $B$ cell secretion (Abstract). Excerpta Med 481: 222

7. Hermansen K (1978) Haloperidol, a dopaminergic agonist: somatostatinlike inhibition of glucagon and insulin release from the isolated, perfused canine pancreas. Diabetologia 15: 343-349

8. Samols E, Stagner JI (1980) Reinterpretation of the effects of haloperidol and ethanol on insulin secretion. Diabetologia 19: $81-83$

9. Stagner J, Samols E, Weir G (1979) Detection of sustained insulin, somatostatin and glucagon oscillations in the isolated perfused canine pancreas (Abstr 7). Proc 61st Ann Endocrine Society Meeting, Anaheim, Ca, p 74

10. Stagner J, Samols E, Weir G (1980) Sustained oscillations of insulin, somatostatin and glucagon secretion by the isolated canine pancreas despite a constant glucose concentration (Abstr 551). Sixth International Congress of Endocrinology, Melbourne, Australia, p 485

11. Stagner JI, Samols E, Weir GC (1980) Sustained oscillations of insulin, glucagon, and somatostatin from the isolated canine pancreas during exposure to a constant glucose concentration. J Clin Invest 65: 939-942

12. Zern RT, Foster LB, Blalock JA, Feldman JM (1979) Characteristics of the dopaminergic and nor-adrenergic systems of the pancreatic islets. Diabetes 28: 185-189

13. Hermansen K, Christensen SE, Orskov H (1979) Characterisation of somatostatin release from the pancreas. The role of calcium and acetylcholine. Diabetologia 16: 261-266

Dr. E. Samols

Research Service

VA Medical Center

800 Zorn Avenue

Louisville, KY 40202

USA 


\section{Discussion after Samols' Presentation}

Goldman: The glucagon response you observed following beta-adrenergic stimulation appeared rather gradual and not at all like the abrupt response to alpha-adrenergic stimulation. Is it possible that the effect of beta stimulation is not a primary one, and that it might represent a paracrine action, perhaps via somatostatin?

Samols: That's hard to evaluate. I doubt that the difference represents a paracrine effect because the total response to beta input is greater than for alpha input. The beta effect is also easier to show at very small doses.

Porte: In general, the changes of somatostatin output you observe seemed relatively small. What natural events stimulate the D-cell and how do they relate to your observed changes? Can you ever see larger changes?

Samols: With some secretagogues such as glucose or glucagon, we have seen increases of up to $200 \%$. Perhaps if we combined these with arginine plus beta-adrenergic agonists, we could stimulate it a little more. But you are correct that in general, the changes we see are small. I don't think that this represents a small number of cells since we see very large effects with pancreatic polypeptide. I have a feeling that you're suggesting that somatostatin may be acting mainly within the islets and we basically agree with that position. If so, what we see in the effluent is essentially an overflow of this activity.

Porte: Have you looked to see if there is an interaction between various levels of glucose and the effectiveness of acetylcholine on somatostatin secretion?

Samols: We 've looked, and it doesn't seem to have much effect.

F. Jeanrenaud: Is it possible to administer antisomatostatin antibodies and block the secretion of somatostatin in your preparation?

Samols: We've tried that. We gave arginine before and after antisomatostatin antiserum and found absolutely no difference. There was also no change of insulin or glucagon. Dr. Weir has been getting some effects with the chicken pancreas, but it is quite different anatomically.

$F$. Jeanrenaud: Do the antibodies have an effect on isolated islets?

Samols: Well, yes, but that's a different story because the antibodies have such ready access to the cells in that preparation.

B. Jeanrenaud: Doesn't that cast some doubt as to a possible paracrine role for somatostatin?
Samols: Actually, I feel that it supports that contention, because if the antibodies work in the isolated islets but not the perfused pancreas, the difference is presumably that very little of the globulin gets through the capillaries normally. Perhaps all of its actions are within the islets.

Brown: Is there any evidence that somatostatin released from the pancreas is biologically functional?

Samols: In terms of the actual concentrations we see here, it's hard to say. One can certainly find evidence on either side, especially for a possible paracrine effect on the $A$ and B-cells. Certainly the extraordinary sensitivity we see to very small amounts of somatostatin suggests a possible local role.

Brown: Yes, but I'm concerned with endogenous pancreatic somatostatin. It's clear that exogenous somatostatin has an effect.

Samols: Yes, I understand what you mean, but I know of no studies which really address the point.

Porte: Have you added somatostatin to your infusate and measured it in the effluent? For example, if you give enough to double the concentration in the venous effluent, what is the effect on insulin and glucagon? This would show what a concentration change such as you observe actually does.

Samols: In the instance you suggested, one sees a significant suppression of insulin and glucagon, of perhaps as much as 80 or $90 \%$. The problem, of course, is knowing whether or not what we measure in the effluent is biologically active.

B. Jeanrenaud: We have evidence that somatostatin is released in an inverse relationship with glucagon and insulin, again suggesting that somatostatin may have an action on the secretion of the other two hormones.

F. Jeanrenaud: Have you looked at influences of the CNS upon somatostatin release?

Samols: Yes, I might just mention some work we have been doing about which I now feel confident. In that preparation, the pancreas is isolated and vascularly perfused in the whole dog in situ, but it has an intact nerve supply. When we give exogenous insulin into the general circulation, we see a small but very rapid increase of insulin and a larger increase of somatostatin in the pancreatic efflux. So perhaps there is a normal role of the CNS here. 